\title{
Systematic Quantitative Literature Review on Criminological Theories in Asia
}

Masahiro Suzuki ${ }^{1}$; Chen-Fu Pai ${ }^{1}$; Md. Jahirul Islam ${ }^{1,2}$

${ }^{1}$ School of Criminology and Criminal Justice, Griffith University, Brisbane, Australia

${ }^{2}$ Ministry of Planning, Bangladesh Planning Commission, Dhaka, Bangladesh

\section{Corresponding Author}

Name: Masahiro Suzuki

Position: Doctoral candidate

Affiliation: School of Criminology and Criminal Justice, Griffith University, Brisbane, Australia Tel: +61(0)7 37351202

Email: masahiro.suzuki@griffithuni.edu.au

\section{Acknowledgement}

Our special thanks are extended to Professor Susanne Karstedt. We also would like to thank Professor Lening Zhang, Professor Kwang-Kuo Hwang, and Navin Kumar for their comments on the early draft of this paper.

Accepted in Asian Journal of Criminology. doi: 10.1007/s11417-017-9262-9 


\begin{abstract}
Empirical work on criminological theories in Asia has been increasing. However, few comprehensive and systematic reviews on the application of criminological theories in Asia have been conducted. Using a systematic quantitative literature review method on peerreviewed English-language journal articles, we aim to provide an overview of the use of five major criminological theories in Asia: (1) strain; (2) social learning; (3) control; (4) routine activity; and (5) developmental and life-course. In particular, we address the following four questions: (1) how often are these theories tested in which region of Asia?; (2) what methodology is used to test these theories?; (3) to what extent are these theories supported in the Asian context?; and (4) what cultural uniqueness in the Asian context is taken into account in testing these theories, and what role and effect do they play in analysis and outcome? Findings indicate that the relationship between these theories and the Asian regions is skewed; many studies do not employ rigorous methodologies; these theories are either fully or partially supported in the Asian context; and only a few studies have analyzed the cultural uniqueness of the Asian context, and no effect of cultural uniqueness of the Asian context was found. Research implications for developing criminology in Asia are discussed.
\end{abstract}

\title{
Keywords
}

Criminology in Asia; criminological theory; comparative criminology; systematic quantitative literature review 


\section{Introduction}

Over the last couple of decades, Asia has become an important area of criminological research due to its economic and political influence in the context of globalization. In what Belknap (2016) called a "powerful" article, Liu (2009) emphasized the need to develop criminology in Asia. He articulated this because while most of the recent major criminological theories have been developed in the US (Liu 2007), "cultures and societies within Asia differ considerably" (Liu 2009, p. 4). The development of criminology in Asia is thus important for considering the comparative criminology perspective. This is particularly the case in criminological theories because, as Liu (2016) argues the need of an Asian paradigm, (causes of) criminal behaviors might be different between the US and Asia.

The development of criminology in Asia is evident in the growing amount of empirical literature on criminological theories. While most extant empirical studies on these theories still originate from the US and other Western countries (Carrington 2017; Jiang and Lambert 2012), the number of originating in Asia has been increasing (Antonaccio and Botchkovar 2016; Belknap 2016; Hebenton and Jou 2013). Yet, few comprehensive and systematic reviews on the application of criminological theories in Asia have been conducted. Due to the differences between Asia and the US (and other Western countries) and within Asia (Liu 2009, 2016), it is important to understand how the existing criminological theories are used in Asia. In this paper, we aim to provide an overall picture of criminological theories in Asia by using the method of systematic quantitative literature review (SQLR) (Pickering and Byrne 2013; Pickering et al. 2015). As will be discussed later, we specifically focus on the following five criminological theories: (1) strain; (2) social learning (SL); (3) control; (4) routine activity (RA); and (5) developmental and life-course (DLC).

We address the following four questions. First, how often are these theories tested in the various regions of Asia? Our intention is to identify whether there is any variation in the 
amounts of literature and numbers of theories tested in each region of Asia. If we are to develop criminology in Asia, we first need to know the overall picture. Second, what methodology (e.g., research design, data collection method, sampling strategy, sample size, etc.) is used? We aim to offer an overview of the methodology used in the extant literature. This will help to provide implications for future research designs in Asia.

Third, to what extent are these theories supported in the Asian context? While theories are invented to be "universal" beyond cultures and societies, some scholars caution against simply applying existing criminological theories in the Asian context (Jiang and Lambert 2012; Joo 2015; Zhang 2008) because the differences between Asia and the US (and other Western countries) might affect criminal and antisocial behaviors among Asian people (Braithwaite 2014; Zhang et al. 2008). Since Antonaccio and Botchkovar (2016) and Belknap (2016) have already conducted a narrative review on how criminological theories are tested in non-Western contexts including Asia, we are more interested in "numerically" (see the discussion on Methodology) understanding the extent to which the theories are supported, and if not, the reasons for failures.

The fourth and final question is about the "cultural uniqueness" of the Asian context which can make Asia different from the West - in using criminological theories in Asia. In relation to cross-cultural criminology, Karstedt (2001, p. 289-290; also see Karstedt 2012) proposes that two analytical strategies exist to examine cultural differences: (1) dimensionalextensive strategy, in which "cultures can be compared with regard to specific dimensions that are common to all" (e.g., individualism/collectivism); and (2) singular-trait-intensive strategy, in which "differences between cultures are shaped by a specific characteristics or singular cultural trait, that pervades the total cultural pattern; it is present in one type of culture, but absent in others" (e.g., Latin-American "Machismo"). Since we are interested in the cultural uniqueness of the Asian context, our focus is on studies that adopt the latter 
strategy: that is, those exploring cultural traits that exist solely in Asia. So, the question is: what type of singular cultural traits that are specific to the Asian context has been taken into account and what role and effect do they play in analysis and outcome? Since which singular cultural trait in Asia should be considered and how we should take it into account remain relatively unknown (c.f., Travers 2017), examining the above question will help future theoretical development in criminology in Asia.

\section{Methodology}

\section{Systematic Quantitative Literature Review}

The idea of a systematic quantitative literature review (SQLR) is recently put forward by Catherine Pickering (Pickering and Byrne 2013; Pickering et al. 2015). The basic philosophy and procedure of SQLR is almost the same as the "traditional" systematic review (Pickering and Byrne 2013). Yet, SQLR differs in what types of research are included. While the traditional systematic review generally focuses on quantitative methods, SQLR can even include qualitative studies. This is because the ultimate goal of SQLR is not to provide “evidence-based" practices by using an effect size with sophisticated statistical techniques; rather, it aims to offer 'knowledge about 'what we know' as well as 'what we don't know' by identifying research trends and gaps" (Pickering et al. 2015, p. 1761). In other words, the focus of SQLR is not on the outcomes of extant studies, such as the statistical power, but on their contents, such as what methodology is used or whether outcomes are positive/neutral/negative. It aims to offer numerical understanding on these aspects.

Since our purpose in this paper is to provide an overall picture of the abovementioned questions in relation to applying criminological theories in Asia, we consider SQLR the most appropriate methodology. The number of papers that employ this method is increasing in various disciplines (see https://www.griffith.edu.au/environment-planning- 
architecture/griffith-school-environment/research/systematic-quantitative-literature-review). However, to our knowledge, this type of literature is scarce in criminology, particularly in the Asian context (c.f., Belknap, 2016; Hebenton and Jou 2013; Liu et al. 2017). By examining the overview of the use of five major criminological theories in Asia with SQLR, we aim to identify geographical, methodological, theoretical and conceptual gaps in the current literature on criminology in Asia in order to contribute to its development. The following outlines the eligibility criteria for our SQLR.

\section{Inclusion and Exclusion Criteria}

Tittle (2016, p. 1) argued that the definition of theory in criminology can vary among scholars, "depending on their philosophies about the nature of criminology, what it is attempting to accomplish, and how they think criminology ought to be done." In this paper, we focused on theories for causes of crime and deviance. We did so because until the recent extensive focus on desistance (i.e., how and why people stop offending), understanding reasons why people commit a crime can arguably be regarded as a priority in criminology (Graham and McNeill 2017) and such theories may be suitable to identify the differences between Asia and the US (and other Western countries).

When it comes to criminological theories for causes of crime and deviance, variations still exist, for example, from micro- to macro-theories (Baumer and Arnio 2016). To determine our focus, we employed the following strategy: we decided to focus on theories that are covered in all three recently published handbooks of criminological theory as a main theme or topic of a chapter (i.e., the theory has been discussed throughout the chapter rather than merely as a section in the chapter) (Cullen and Wilcox 2013; McLaughlin and Newburn 2010; Piquero 2016). This left the following five criminological theories: (1) strain, (2) social learning (SL), (3) control, (4) routine activity (RA), and (5) developmental and life-course (DLC). 
With regard to the definition of Asia, we followed the list of Asian countries offered by the United Nations Statistics Division (UNSD) (2016). According to the UNSD, there are total $51(52)^{1}$ countries in five regions (see Table 1$)$.

Table 1 List of Asian countries

\begin{tabular}{ll}
\hline Region & Country \\
\hline Central $(\mathrm{n}=5)$ & Kazakhstan, Kyrgyzstan, Tajikistan, Turkmenistan, Uzbekistan \\
Eastern $(\mathrm{n}=7(8))$ & $\begin{array}{l}\text { China, Hong Kong (Special Administrative Region), Macao (Special } \\
\text { Administrative Region), Democratic People's Republic of Korea, Japan, } \\
\text { Mongolia, Republic of Korea, (Taiwan) }\end{array}$ \\
& $\begin{array}{l}\text { Afghanistan, Bangladesh, Bhutan, India, Iran (Islamic Republic of), Maldives, } \\
\text { Nepal, Pakistan, Sri Lanka }\end{array}$ \\
Southern $(\mathrm{n}=9)$ & $\begin{array}{l}\text { Brunei Darussalam, Cambodia, Indonesia, Lao People's Democratic Republic, } \\
\text { Malaysia, Myanmar, Philippines, Singapore, Thailand, Timor-Leste, Viet Nam }\end{array}$ \\
South-Eastern $(\mathrm{n}=11)$ & $\begin{array}{l}\text { Armenia, Azerbaijan, Bahrain, Cyprus, Georgia, Iraq, Israel, Jordan, Kuwait, } \\
\text { Lebanon, Oman, Qatar, Saudi Arabia, State of Palestine, Syrian Arab Republic, } \\
\text { Turkey, United Arab Emirates, Yemen }\end{array}$ \\
\hline
\end{tabular}

We adopted the following criteria to select studies. First, we have targeted peer-reviewed journal articles. Wilson (2009) warns that solely focusing on peer-reviewed journal articles in systematic methods is problematic because "grey" literature - unpublished works and reports by research institutions or government agencies - can be as significant as those of peer-reviewed journal articles. However, since there are relatively fewer governmental and independent research institutions that publish original studies in Asia (Mei and Wang 2007; Yokoyama 2013), focusing on peer-reviewed journal articles would be less likely to raise a problem in the Asian context. Second, we focused on original empirical research. For the empirical research, as discussed above, we included all types of research including not only quantitative but also qualitative and mixed-method studies. Third, we limited our search to English-written literature. Although we had a privilege of being capable of searching in three

\footnotetext{
${ }^{1}$ While Taiwan is not listed as an Asian country in the UNSD list, we decided to include it because numerous empirical studies have been conducted independently in Taiwan (Hebenton and Jou 2013).
} 
languages due to the authors' backgrounds (i.e., Japanese, Chinese, and Bengali), we decided to rely solely on English-written languages in order to be equitable to other languages in Asia. While there is a language barrier in publishing research articles in English for criminologists in Asia whose first language is not English, the number of journal articles written by criminologists in Asia has been increasing (Hebenton and Jou 2013; Liu et al. 2013). In addition, because criminology as a discipline and knowledge is derived mainly from English-speaking countries, the "common language" for criminologists is arguably English. Hence, publishing research articles in English is important for criminologists in Asia because it will help to disseminate knowledge on how Asia can be different from the US and other Western countries in terms of crime and control (Liu 2009). Finally, we excluded crosssectional studies that were conducted in more than two countries unless they are all Asian countries. We made this decision because our focus is on regions in Asia, not other regions or countries.

\section{Search Strategies}

Conducting SQLR requires a thorough database search. In this regard, Wilson (2009, p. 433) argued that for the result of systematic methods to be comprehensive, more than one database is required because "no single bibliographic database provides adequate coverage to be relied on as the sole source for identifying studies in crime and justice." To make a comprehensive literature list for the SQLR, we therefore used the following three databases: Sociological Abstracts, Criminal Justice Abstracts, and PsycINFO. We chose these databases because they cover different disciplines relevant to criminology.

The literature search was conducted between May and July 2016. The aforementioned databases were searched with keywords using the following combination: (keyword(s) for criminological theory) AND (keyword(s) for country) AND (crim*² OR delinquen* OR

\footnotetext{
2 “*” indicates a wildcard. Note that the wildcard in the Criminal Justice Abstracts is "'?".
} 
offen*). Table 2 shows the keywords for the five criminological theories we focused on. With respect to the keyword(s) for Asian countries, we used a wildcard to include both a country itself and its citizens (e.g., "Japan*” for Japan as a country and Japanese people).

Table 2 Keywords for criminological theories

\begin{tabular}{ll}
\hline Theory & Keywords \\
\hline Strain & general strain theory OR strain \\
SL & social learning OR differential association \\
Control & control OR social control OR social bond OR self-control OR power-control \\
RA & routine activit* OR lifestyle \\
DLC & life-course OR risk factor OR criminal career OR age-crime curve OR developmental pathway \\
\hline
\end{tabular}

Figure 1 describes the screening process of our SQLR. To screen the search outcomes, we employed the following two steps. First, after obtaining the search results with the abovementioned keywords, we checked the title and abstract to identify whether the journal articles matched our eligibility criteria. At this stage, duplicated articles were excluded. When uncertain, those articles were retained for the next step. Second, we read the whole article to check whether the journal articles screened were consistent with our criteria. After all, we identified 118 journal articles.

Figure 1 Screening process

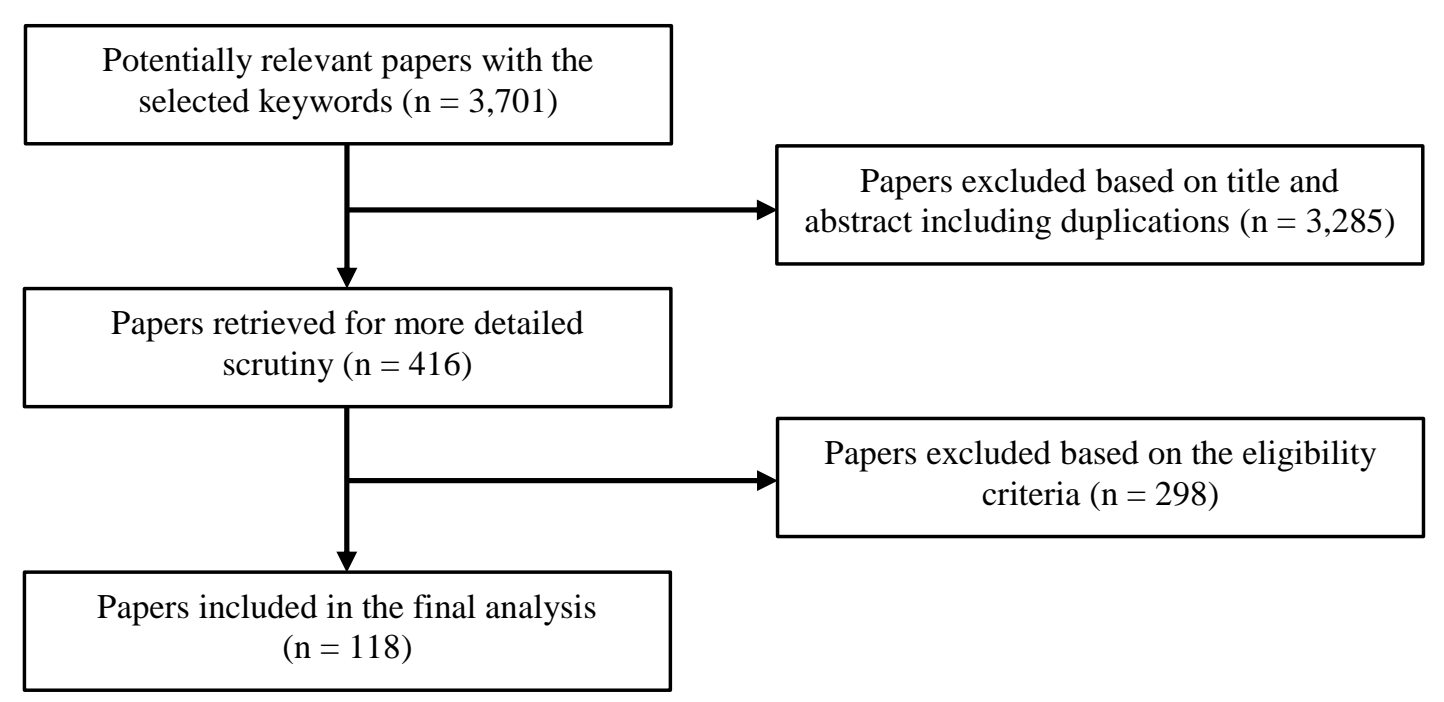




\section{Results}

Based on the journal articles identified as per our eligibility criteria $(n=118)$, this section describes the outcome of our SQLR search. Each section corresponds with the four research questions respectively: (1) how often these theories are tested in which region of Asia?; (2) what methodology is used?; (3) to what extent are these theories are supported in the Asian context?; and (4) what cultural uniqueness of the Asian context has been taken into account and what role and effect do they play in analysis and outcome?

\section{Relationship between Theories and Asian Regions}

In relation to the number of articles in each Asian region, the majority of them originated from Eastern Asia $(67.5 \%, n=83)$, significantly from South Korea $(n=27)$, China $(n=20)$, and Hong Kong $(\mathrm{n}=17)$. The region that produced the second most number of articles is Western Asia $(22.0 \%, \mathrm{n}=27)$. But, most of the articles in this region originated from two specific countries, Israel $(n=18)$ and Turkey $(n=7)$. The number of other regions in Asia that produced relevant articles is significantly small: South Eastern Asia $(8.9 \%, n=11)$, Southern Asia $(1.6 \%, \mathrm{n}=2)$. We could not find any articles in Central Asia.

When closely looking at each theory in conjunction with each region in Asia, the results show another skewed trend (Figure 2). Among the five criminological theories, control is the most tested $(41.1 \%, n=62)$, while the majority of articles sill come from Eastern Asia $(n=$ 49). This is followed by strain $(21.2 \%, \mathrm{n}=32)$, DLC $(17.9 \%, \mathrm{n}=27), \operatorname{SL}(14.6 \%, \mathrm{n}=22)$ and RA $(5.3 \%, n=8)$. Yet, no articles were found for strain in Southern Asia, for RA in Southern and South Eastern Asia, and for DLC in Southern Asia. 
Figure 2 Number of articles by theories and Asian regions $(\mathrm{N}=118)^{3}$

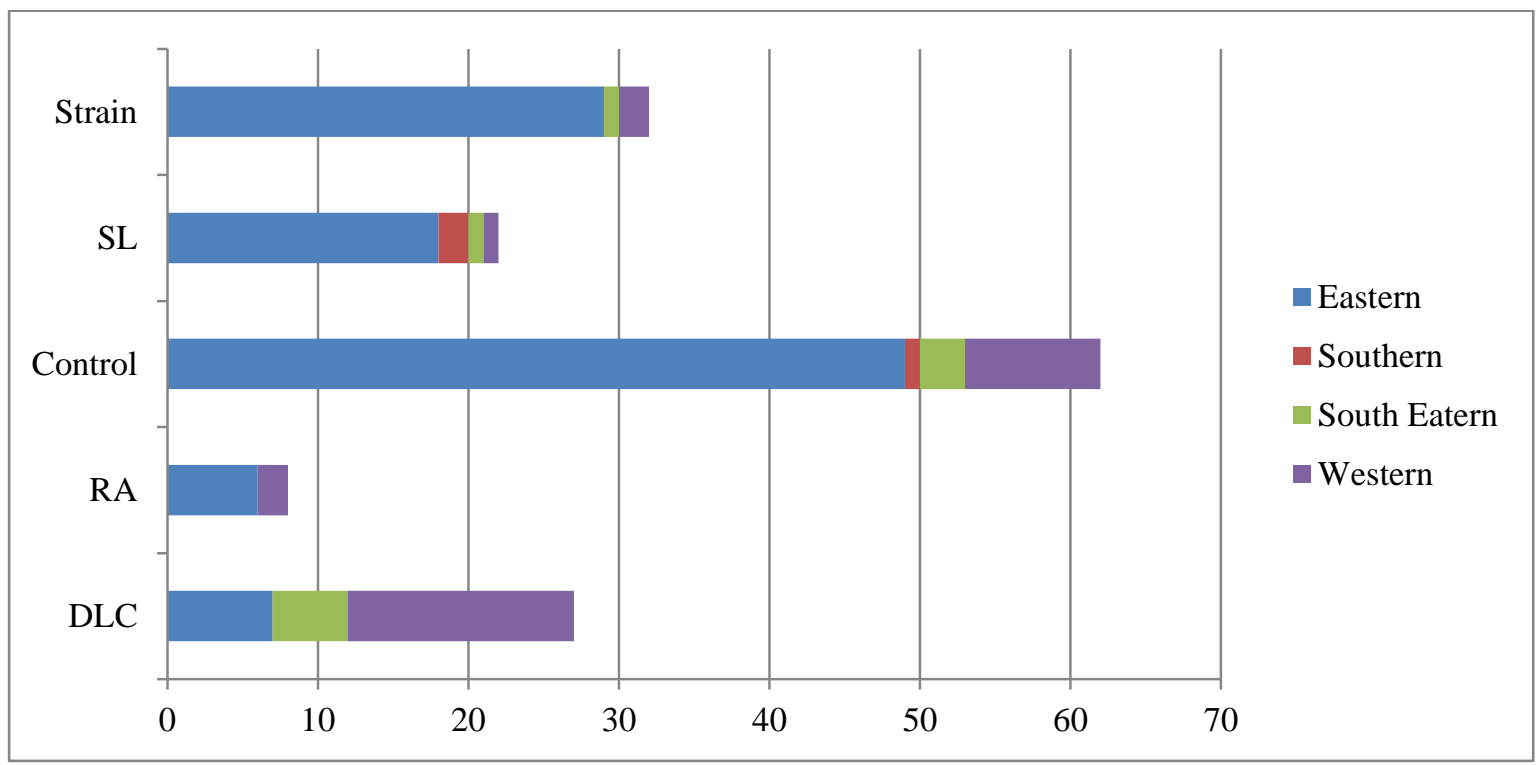

\section{Methodological Choices}

Table 3 summarizes the methodology adopted in the articles identified by our SQLR search. In Asia, the five criminological theories tend to have been tested with a particular research approach and design. Most articles relied on a quantitative approach $(91.5 \%, \mathrm{n}=$ $108)$ and cross-sectional approach $(71.9 \%, \mathrm{n}=97)$. The similar trend is evident in the data collection method. The most common data collection method is survey $(81.1 \%, \mathrm{n}=99)$. Other data collection methods were infrequently used: interview $(8.2 \%, \mathrm{n}=10)$, secondary data $(9.8 \%, \mathrm{n}=12)$, and observation $(0.8 \%, \mathrm{n}=1)$. In relation to the sampling method, around less than half of the articles adopted a probability sampling method $(46.3 \%, \mathrm{n}=56)$. Yet, in a certain number of articles $(27.3 \%, \mathrm{n}=33)$, it is not clear which sampling method was employed, although most are assumed to have been non-probability. Similarly, the sample size also varied. Less than half of the articles had more than 1,000 respondents $(39.8 \%, \mathrm{n}=47)$, while just fewer than a quarter of articles had more than 500 respondents $(22.9 \%, \mathrm{n}=27)$ and more than 100 respondents $(23.7 \%, \mathrm{n}=28)$. As for type of offenders, the majority of studies focused on juvenile offenders $(64.8 \%, \mathrm{n}=81)$, and relatively few articles

\footnotetext{
${ }^{3}$ Since no article was found in the literature search, Central Asia is not included.
} 
dealt with female offenders $(9.6 \%, \mathrm{n}=12)$. In relation to type of offence, near three-fifth of the articles $(61.0 \%, \mathrm{n}=72)$ targeted crime in general and the second largest number of studies $(10.2 \%, \mathrm{n}=12)$ focused on substance use or drug-related crime.

Table 3 Summary of methodology used in identified journal articles $(\mathrm{N}=118)$

\begin{tabular}{|c|c|}
\hline Category $^{\mathrm{a}}$ & Frequency $(\%)$ \\
\hline \multicolumn{2}{|l|}{ Research approach $^{\text {b }}$} \\
\hline Quantitative & $91.5(\mathrm{n}=108)$ \\
\hline Qualitative & $5.9(\mathrm{n}=7)$ \\
\hline Mixed-method & $2.5(\mathrm{n}=3)$ \\
\hline \multicolumn{2}{|l|}{ Research design $^{c}$} \\
\hline Experiment & $0.7(\mathrm{n}=1)$ \\
\hline Cross-sectional & $71.9(\mathrm{n}=97)$ \\
\hline Longitudinal & $16.3(\mathrm{n}=22)$ \\
\hline Case study & $0.0(\mathrm{n}=0)$ \\
\hline Comparative & $11.1(\mathrm{n}=15)$ \\
\hline \multicolumn{2}{|l|}{ Data collection method } \\
\hline Survey $^{\mathrm{d}}$ & $81.1(\mathrm{n}=99)$ \\
\hline Interview $^{\mathrm{e}}$ & $8.2(\mathrm{n}=10)$ \\
\hline Observation & $0.8(\mathrm{n}=1)$ \\
\hline Secondary data ${ }^{\mathrm{f}}$ & $9.8(\mathrm{n}=12)$ \\
\hline \multicolumn{2}{|l|}{ Sampling method } \\
\hline Probability & $46.3(\mathrm{n}=56)$ \\
\hline Non-probability & $26.4(\mathrm{n}=32)$ \\
\hline Unknown or Not Applicable & $27.3(\mathrm{n}=33)$ \\
\hline \multicolumn{2}{|l|}{ Sample size } \\
\hline $1000 \leq \mathrm{n}$ & $39.8(\mathrm{n}=47)$ \\
\hline $500 \leq \mathrm{n}<1000$ & $22.9(\mathrm{n}=27)$ \\
\hline $100 \leq \mathrm{n}<500$ & $23.7(\mathrm{n}=28)$ \\
\hline $50 \leq \mathrm{n}<100$ & $6.8(\mathrm{n}=8)$ \\
\hline $\mathrm{n}<50$ & $3.4(n=4)$ \\
\hline Unknown or Not Applicable ${ }^{g}$ & $3.4(n=4)$ \\
\hline \multicolumn{2}{|l|}{ Type of offender } \\
\hline Adult & $21.6(\mathrm{n}=27)$ \\
\hline Juvenile & $64.8(\mathrm{n}=81)$ \\
\hline Both adult and juvenile & $4.0(\mathrm{n}=5)$ \\
\hline Female & $9.6(\mathrm{n}=12)$ \\
\hline \multicolumn{2}{|l|}{ Type of offence } \\
\hline Not specific & $61.0(\mathrm{n}=72)$ \\
\hline Theft & $1.7(\mathrm{n}=2)$ \\
\hline Robbery & $0.8(\mathrm{n}=1)$ \\
\hline Burglary & $0.8(\mathrm{n}=1)$ \\
\hline Physical assault & $3.4(n=4)$ \\
\hline Homicide & $2.5(\mathrm{n}=3)$ \\
\hline Domestic $^{\mathrm{h}}$ or intimate partner violence & $5.9(\mathrm{n}=7)$ \\
\hline Sexual assault & $2.5(\mathrm{n}=3)$ \\
\hline Cybercrime & $4.2(\mathrm{n}=5)$ \\
\hline
\end{tabular}




\begin{tabular}{ll}
\hline Bullying & $4.2(\mathrm{n}=5)$ \\
Substance use or drug-related & $10.2(\mathrm{n}=12)$ \\
Fraud & $0.8(\mathrm{n}=1)$ \\
Corporate crime & $0.8(\mathrm{n}=1)$ \\
Antisocial behavior or deviance & $0.8(\mathrm{n}=1)$ \\
\hline
\end{tabular}

${ }^{a}$ Because of the rounding error, the sum of frequency (\%) is not 100 in some categories.

${ }^{\mathrm{b}}$ We adopted Cresswell's (2014) classification on research approach.

'We adopted Bryman's (2016) classification on research design.

d "Survey" includes written questionnaires and structured interviews.

e "Interview" means qualitative (semi-structured and unstructured) interviews.

$\mathrm{f}$ "Secondary data" includes official statistics $(\mathrm{n}=9)$.

g "Unknown" or "Not applicable" include articles that employed secondary data.

${ }^{\mathrm{h}}$ This includes child abuse.

\section{Extent of Theory Support in the Asian Context}

Since our aim for this question is to examine the extent to which theories we focused on are supported in the Asian context, we decided to limit our investigation to "relatively rigorous" studies among those we have identified. Drawing on the foregoing result, we assessed the rigorousness of the studies based on: (1) whether the study adopted a quantitative approach; ${ }^{4}(2)$ whether the study employed a probability sampling method; and (3) whether the study had more than 1000 sample size. This left 28 journal articles.

To determine the extent of which the theories are supported, we read the whole article, particularly focusing on the sections of Abstract, Discussion and Conclusion. Subsequently, we classified studies into three categories: fully supported, partially supported, or not supported. The following describes how we classified studies into these three categories. If studies found a "complete" relationship between the theories and the targeted deviant behaviors, they were classified as "fully supported." If research found only a partial relationship between theories and deviant behavior (e.g., some domains or factors of the theories failed to explain the relationship), these were classified as "partially supported." If studies indicate no relationship between the theories and deviant behaviors, they were classified as "not supported."

\footnotetext{
${ }^{4}$ This includes studies that employed mixed methods.
} 
Table 4 summarizes 28 journal articles in terms of theory, country, offence type, and extent of theory support (if "partially supported" or "not supported," excerpts for the reasons are provided). In case of studies testing two theories, both results are presented. ${ }^{5}$ The result showed that these studies were conducted in countries where more research on criminological theories originated (see the previous section), such as South Korea $(\mathrm{n}=12)$ or Hong Kong ( $=6)$. The majority of them focused on delinquency in general $(n=20)$. In terms of the extent of theory support, the number of "partially supported" $(n=17)$ slightly outweighed that of "fully supported" $(\mathrm{n}=15)$. None of the studies were classified as "not supported." When closely looking at each theory, all studies in SL $(n=3)$ and RA $(n=1)$ were classified as "fully supported." Although the total number of studies was smaller than that of other theories $(\mathrm{n}=2)$, the numbers of research categorized as "fully supported" and "partially supported" were equal in DLC ( $\mathrm{n}=1$, respectively). Only among studies on Strain $(\mathrm{n}=9)$ and Control $(\mathrm{n}=17)$, the numbers of "partially supported" ( $\mathrm{n}=7$ and 9 respectively) outweighed those of "fully supported" ( $n=2$ and 8 respectively). As for the reasons for "partially supported," although most of them were that some domains or factors merely failed to explain the relationship between the theories and deviant behaviors $(\mathrm{n}=10)$, others are concentrated on gender differences $(n=7)$.

\footnotetext{
${ }^{5}$ For this reason, the number of the journal articles and the total sum of "fully supported," "partially supported" and "not supported" are not consistent.
} 
Table 4 Summary of journal articles for the extent of theory support in the Asian context $(\mathrm{N}=28)$

\begin{tabular}{|c|c|c|c|c|}
\hline Article & Theory & Country & Offence type & Extent of theory support \\
\hline Lin (2012) & Strain & Taiwan & $\begin{array}{l}\text { Delinquency in } \\
\text { general }\end{array}$ & Fully supported \\
\hline Cheung and Cheung (2010) & $\begin{array}{l}\text { Strain, } \\
\text { Control }\end{array}$ & Hong Kong & $\begin{array}{l}\text { Delinquency in } \\
\text { general }\end{array}$ & $\begin{array}{l}\text { Fully supported for Strain } \\
\text { Partially supported for Control because of "a partial explanation for the gender gap } \\
\text { in delinquency by elaborating the gender disparity in strain moderation of self- } \\
\text { control" (p. 339) }\end{array}$ \\
\hline Lin and Yi (2016) & Strain & Taiwan & $\begin{array}{l}\text { Delinquency in } \\
\text { general }\end{array}$ & $\begin{array}{l}\text { Partially supported because "complex relationships between strain, negative } \\
\text { emotions, non-emotive concepts, and delinquency are also found" (p. 515) }\end{array}$ \\
\hline Gao et al. (2016) & Strain & China & $\begin{array}{l}\text { Delinquency in } \\
\text { general }\end{array}$ & $\begin{array}{l}\text { Partially supported because "the extended model was found to more accurately } \\
\text { reflect the mechanism of leading adolescent maltreatment to delinquency, and the } \\
\text { original GST model only received partial support due to the failed mediating effects } \\
\text { of state negative emotions" (p. 52) }\end{array}$ \\
\hline Jang and Song (2015) & Strain & South Korea & $\begin{array}{l}\text { Delinquency in } \\
\text { general }\end{array}$ & $\begin{array}{l}\text { Partially supported because of "little evidence that combining variables conducive to } \\
\text { criminal coping is likely to help detect their conditioning effects than using the } \\
\text { variables individually" (p. 419) }\end{array}$ \\
\hline Yun et al (2014) & Strain & South Korea & $\begin{array}{l}\text { Delinquency in } \\
\text { general }\end{array}$ & $\begin{array}{l}\text { Partially supported because "some culture-specific aspects, which means that } \\
\text { gendered GST pathways to delinquency have some general applicability, but specific } \\
\text { gendered pathways from strain through negative emotionality and conditioning } \\
\text { factors toward deviance depend not only on specific combination of types of strains, } \\
\text { negative emotions, conditioning factors, and deviance but also on specific types of } \\
\text { cultural settings" (p. 286) }\end{array}$ \\
\hline Moon et al. (2012) & Strain & South Korea & School bullying & $\begin{array}{l}\text { Partially supported because of "limited support for the interaction effects between } \\
\text { strains and conditioning factors on school bullying" (p. 827) }\end{array}$ \\
\hline Cheung et al. (2007) & Strain & $\begin{array}{l}\text { Hong Kong, } \\
\text { China }\end{array}$ & $\begin{array}{l}\text { Delinquency in } \\
\text { general }\end{array}$ & $\begin{array}{l}\text { Partially supported because "while parental support is notably effective for reducing } \\
\text { adolescent delinquency in Hong Kong, it is not so in Guangzhou, where it is } \\
\text { positively related to delinquency among adolescents whose mothers are not } \\
\text { working" (p. 637) }\end{array}$ \\
\hline Özbay and Özcan (2006) & Strain & Turkey & $\begin{array}{l}\text { Delinquency in } \\
\text { general }\end{array}$ & $\begin{array}{l}\text { Partially supported because "various strain and class measures do not appear to be } \\
\text { associated consistently with delinquency and gender, except for blocked opportunity } \\
\text { for females" (p. 21) }\end{array}$ \\
\hline Kim et al. (2013) & SL & South Korea & $\begin{array}{l}\text { Delinquency in } \\
\text { general }\end{array}$ & Fully supported \\
\hline Kim et al. (2010) & $\begin{array}{l}\text { SL, } \\
\text { Control }\end{array}$ & South Korea & Substance use & Fully supported for both SL and Control \\
\hline Lee et al. (2016) & $\begin{array}{l}\text { SL, } \\
\text { Control }\end{array}$ & South Korea & Sexting behavior & $\begin{array}{l}\text { Fully supported for SL } \\
\text { Partially supported for Control because "social control was negatively related to only }\end{array}$ \\
\hline
\end{tabular}




\begin{tabular}{|c|c|c|c|c|}
\hline & & & & Denaviors (p. 24L) \\
\hline Sacarellos et al. (2016) & Control & $\begin{array}{l}\text { Saudi } \\
\text { Arabia }\end{array}$ & $\begin{array}{l}\text { Delinquency in } \\
\text { general }\end{array}$ & Fully supported \\
\hline Chan and Wong (2015) & Control & Hong Kong & School bullying & Fully supported \\
\hline Jo $(2015)$ & Control & South Korea & $\begin{array}{l}\text { Delinquency in } \\
\text { general }\end{array}$ & Fully supported \\
\hline Cheung (2014) & Control & Hong Kong & $\begin{array}{l}\text { Substance use, } \\
\text { delinquency in general }\end{array}$ & Fully supported \\
\hline Lu et al. (2013) & Control & China & Youth risky behavior & Fully supported \\
\hline Moon et al. (2010) & Control & South Korea & Computer crime & Fully supported \\
\hline Tanioka and Glaser (1991) & $\begin{array}{l}\text { Control, } \\
\text { RA }\end{array}$ & Japan & $\begin{array}{l}\text { Delinquency in } \\
\text { general }\end{array}$ & Fully supported for both Control and RA \\
\hline Jo and Zhang (2014) & Control & South Korea & $\begin{array}{l}\text { Delinquency in } \\
\text { general }\end{array}$ & $\begin{array}{l}\text { Partially supported because "for females, only the relationship between parenting } \\
\text { and self-control was significant, but other associations, such as parenting- } \\
\text { delinquency, and self-control-delinquency, were not statistically significant." (p. } \\
\text { 1355) }\end{array}$ \\
\hline Ünal and Çukur (2011) & Control & Turkey & $\begin{array}{l}\text { Delinquency in } \\
\text { general }\end{array}$ & $\begin{array}{l}\text { Partially supported because "Although the relationships of attachment to teacher and } \\
\text { inductive discipline techniques to delinquency resulted as expected, the relationships } \\
\text { were not statistically significant" (p. 566) }\end{array}$ \\
\hline Yun and Walsh (2011) & Control & South Korea & $\begin{array}{l}\text { Delinquency in } \\
\text { general }\end{array}$ & $\begin{array}{l}\text { Partially supported because "our correlational analysis that partially taps within- } \\
\text { individual stability of self-control showed that self-control was not as stable as } \\
\text { Gottfredson and Hirschi would have expected" (p. 455) }\end{array}$ \\
\hline Jo and Bouffard (2014) & Control & South Korea & $\begin{array}{l}\text { Delinquency in } \\
\text { general }\end{array}$ & $\begin{array}{l}\text { Partially supported because of "partial support for Gottfredson and Hirschi's position } \\
\text { that one general theory can be applied to explain both male and female crimes" (p. } \\
363 \text { ) }\end{array}$ \\
\hline Moon et al. (2013) & Control & South Korea & Computer crime & $\begin{array}{l}\text { Partially supported because "boys are more likely than girls to be involved in } \\
\text { computer crime, but the results indicate that low self-control and opportunity factors } \\
\text { are not effective in mediating the impact of gender" (p. } 474)\end{array}$ \\
\hline Chui and Chan (2012b) & Control & Hong Kong & $\begin{array}{l}\text { Delinquency in } \\
\text { general }\end{array}$ & $\begin{array}{l}\text { Partially supported because "involvement in organizational activities in general was } \\
\text { found to have negative relationship with male and female delinquency" (p. 383) }\end{array}$ \\
\hline Cheung and Cheung (2008) & Control & Hong Kong & $\begin{array}{l}\text { Delinquency in } \\
\text { general }\end{array}$ & $\begin{array}{l}\text { Partially supported because "self-control fails to predict delinquency when social } \\
\text { variables [measuring a number of other competing theoretical domains] are } \\
\text { controlled for among Chinese adolescents" (p. 412) }\end{array}$ \\
\hline Yi et al (2011) & DLC & Cambodia & Substance use & Fully supported \\
\hline Lee and Bukowski (2012) & DLC & South Korea & $\begin{array}{l}\text { Delinquency in } \\
\text { general }\end{array}$ & $\begin{array}{l}\text { Partially supported because "some risk factors have common effects on both } \\
\text { domains and both genders, whereas others have unique effects despite their } \\
\text { concurrent association across domain and gender" (p. 725) }\end{array}$ \\
\hline
\end{tabular}




\section{Cultural Uniqueness of the Asian Context}

To identify which journal articles has taken account the singular cultural trait that is unique to Asia in their analytical models, we focused on qualitative studies $(n=111){ }^{6}$ Further, we adopted the following procedure: (1) we read the introduction and literature review sections of each article to check if it refers to the uniqueness of the Asian context; and (2) if mentioned any, we then read the methodology section to check whether the singular cultural trait in the Asian context that is referred to in the introduction or the literature review section is incorporated into the analytical model.

While a certain number of articles referred to the uniqueness in the Asian context in relation to criminal and deviant behavior in their introduction or discussion sections and some articles have taken account for multi-dimensional concepts of culture, the number of the articles that actually incorporated singular cultural traits that are specific to Asia in their analytical models is small. Of 111 quantitative research identified, we found that only four journal articles did so. In addition, these singular cultural traits in the Asian context are limited to religious or ethical systems: Buddhism $(n=2)$, Confucianism $(n=2)$, and Daoism $(\mathrm{n}=1)$.

Table 5 summarizes journal articles that incorporated the singular cultural trait in the Asian context into their analytical models for which theory, country, offence type, measurement, role in the analytical model, and the result. As an independent variable of Control, Confucianism was measured by Ornatowski's (1996) scale and analyzed for delinquency in general in Hong Kong. Similarly, as independent variables of Control, Confucianism and Daoism were measured by Dien's (1983) scale and analyzed for child maltreatment in Vietnam. Neither research showed effect of Confucianism and Daoism on the targeted deviant behaviors. As one of socio-demographic characteristics, Buddhism was

\footnotetext{
${ }^{6}$ Consistent with the previous section, this includes studies with mixed methods.
} 
incorporated as a control variable of SL and Control for family and intimate partner violence in the Thai context. This is because Buddhism, which has "non-violent nature" (Kerley et al. 2010, p. 346) and "encourages tolerance and individual initiative" (Kerley et al. 2008, p. 526), could affect family and intimate partner violence in Thailand. Consequently, its effect was not analyzed in these studies. 
Table 5 Summary of journal articles that have taken account for uniqueness of the Asian context

\begin{tabular}{|c|c|c|c|c|c|c|c|}
\hline Article & Theory & Country & $\begin{array}{l}\text { Offence } \\
\text { type }\end{array}$ & $\begin{array}{l}\text { Singular } \\
\text { cultural trait }\end{array}$ & Measurement & $\begin{array}{l}\text { Role in the } \\
\text { analytical } \\
\text { model }\end{array}$ & $\begin{array}{l}\text { Results on the effects of the uniqueness of the } \\
\text { Asian context }\end{array}$ \\
\hline $\begin{array}{l}\text { Emery et } \\
\text { al. }(2014)\end{array}$ & Control & Vietnam & $\begin{array}{l}\text { Child } \\
\text { maltreatment }\end{array}$ & Confucianism & $\begin{array}{l}\text { (1) "a high public regard for } \\
\text { education and widespread use of } \\
\text { meritocratic entrance exams" } \\
\text { (2) "an emphasis mutual obligations } \\
\text { between superior and inferior" } \\
\text { (3) "an overall stress on 'social } \\
\text { harmony' as opposed to } \\
\text { individualism, i.e. the individual } \\
\text { 'fitting' himself into groups based } \\
\text { on performing the proper role and } \\
\text { groups doing the same vis a vis } \\
\text { society" (Ornatowski 1996, p. 574) }\end{array}$ & $\begin{array}{l}\text { Independent } \\
\text { variable }\end{array}$ & $\begin{array}{l}\text { No effect: "Because the Confucian beliefs variable } \\
\text { did not have a significant relationship with either } \\
\text { abuse or neglect in any of the models run, it is } \\
\text { dropped from further analyses" (p. 1241) }\end{array}$ \\
\hline $\begin{array}{l}\text { Ngai and } \\
\text { Cheung } \\
(2005)\end{array}$ & Control & $\begin{array}{l}\text { Hong } \\
\text { Kong }\end{array}$ & $\begin{array}{l}\text { Delinquency } \\
\text { in general }\end{array}$ & $\begin{array}{l}\text { Confucianism, } \\
\text { Daoism }\end{array}$ & $\begin{array}{l}\text { (1) "Endorsement of Confucian } \\
\text { ethics: How much do you agree with } \\
\text { various Confucian values (Dien } \\
1983) \text { ?" ( } 5 \text { items) (p. 452) } \\
\text { (2) "Endorsement of Daoist ethics: } \\
\text { How much do you agree with } \\
\text { various Daoist values (Dien 1983)?" } \\
\text { ( } 5 \text { items) (p. 452) }\end{array}$ & $\begin{array}{l}\text { Independent } \\
\text { variable }\end{array}$ & $\begin{array}{l}\text { No effect: "Moral belief, or disapproval of } \\
\text { offenses, also promotes social control. Although } \\
\text { endorsement of Confucian and Daoist ethics shows } \\
\text { no significant impact on the likelihood of crime or } \\
\text { delinquency, they demonstrate correlations with } \\
\text { delinquent likelihood in the expected direction. } \\
\text { They are also integral components of social } \\
\text { control, which is the strongest factor preventing the } \\
\text { marginal youths delinquency" (p. 461) }\end{array}$ \\
\hline $\begin{array}{l}\text { Kerley et } \\
\text { al. }(2010)\end{array}$ & SL & Thailand & $\begin{array}{l}\text { Family } \\
\text { violence }\end{array}$ & Buddhism & $\begin{array}{l}\text { "dummy coded with other faith } \\
\text { traditions as the reference" (p.341) }\end{array}$ & $\begin{array}{l}\text { Control } \\
\text { variable }\end{array}$ & Not applicable \\
\hline $\begin{array}{l}\text { Kerley et } \\
\text { al. }(2008)\end{array}$ & Control & Thailand & $\begin{array}{l}\text { Intimate } \\
\text { partner } \\
\text { violence }\end{array}$ & Buddhism & $\begin{array}{l}\text { "dummy coded with other faith } \\
\text { transitions as the reference" (p. 515) }\end{array}$ & $\begin{array}{l}\text { Control } \\
\text { variable }\end{array}$ & Not applicable \\
\hline
\end{tabular}




\section{Discussion}

While the number of criminological literature on Asia is growing, fewer studies are involved in comprehensive and systematic reviews on the application of criminological theories in Asia. Using the SQLR method, we have offered an overall picture of the five major criminological theories in Asia: (1) strain, (2) SL, (3) control, (4) RA, and (5) DLC. Since our eligibility criteria is English-written peer-reviewed journal articles on these five theories, our finding might have missed some literature. For example, although social disorganization theory has been tested in Japan (Takagi and Kawachi 2014) and China (Jiang et al. 2013), our result does not include these literature because this theory is not in our eligibility criteria. Also, our result does not include journal articles written in non-English languages, book chapters or dissertations. Despite these limitations, however, we have identified 118 journal articles that have examined these five theories in Asia. Based on the findings in response to our four research questions - (1) relationship between theories and Asian regions; (2) methodological choices; (3) extent of theory support in the Asian context; and (4) cultural uniqueness of the Asian context - in this section we offer a future direction in developing criminology in Asia.

The most obvious trend in the relationship between the theories and the Asian regions is skewed. The existing knowledge on criminological theories in the Asian context is significantly biased towards Eastern Asia and Control. This remains a challenge if scholars intend to develop "indigenous" criminology in Asia because Asia consists of diverse cultures, religions, politics, and economies (Konishi 2013; Liu 2009). For instance, it would be hard to say that even if both are located in Asia, Japan and Bangladesh would be culturally, religiously, politically, and economically similar. To grasp the effect of diversity within Asia, more empirical studies need to be undertaken in the Southern, South Eastern and Central Asian regions, especially in relation to RA and DLC theories. 
In relation to methodology, there is much room for improvement. First, more longitudinal studies with a comparison group are needed. Lack of longitudinal studies and a comparison group makes the causal mechanism less certain for these criminological theories in the Asian context (Antonaccio and Botchkovar 2016; Zhang 2008). Such a gap can be an obstacle to developing criminology in Asia, given the potential differences in criminal behavior and control between Asia and the US and other Western countries. Second, quality and availability of official data need to be improved. Compared to Western countries, the availability of official data on crime is relatively limited (Lee and Laidler 2013; Liu 2007; Zhang et al. 2008). Not only is the validity of official data questioned (Broadhurst and Liu 2004), but authorities are somewhat reluctant to provide crime-related data in some Asian countries (Zhang et al. 2007). This makes it difficult for criminologists in Asia to be competitive, while scholars in the West enjoy the luxury of availability of official data. Third, random sampling should be adapted in more studies. Lack of probability sampling strategy questions the quality of data (Zhang 2008). Given this, and the aforementioned methodological problems, more methodologically rigorous studies are needed.

Consistent with other studies (e.g. Marshall and Enzmann 2012), examination on the extent of theory support in the Asian context revealed that the selected theories are fully or at least partially supported in the Asian context. This may lead to the argument that existing major criminological theories, particularly SL and RA, are applicable beyond cultures and geography. Yet, it is important to remind the need for further investigation because some studies failed to fully support the theories. Especially, more research need to be conducted to examine differences between female and male offenders in the Asian context because some of the studies identified were classified as "partially supported" due to gender differences. This need can be further justified given the limited number of studies that focus on female offenders in the Asian context. 
To develop criminology in Asia, it is crucial to "develop a basic understanding of the features of Asian cultures and societies, and of how these key features are related to crime and crime control practices" (Liu 2009, p. 4). This may be of particular importance because, as the above discussion suggests, some of the criminological theories are not fully supported in the Asian context. However, our results show that few articles attempted to consider the uniqueness of the Asian context. In other words, criminologists in Asia tend to test existing major criminological theories in Asian countries without modifications (Hebenton and Jou 2005; Lee and Laidler 2013). This may be partly due to the fact what singular cultural trait in Asia should be considered and how we should take it into account remain relatively unknown (c.f., Travers 2017). We need to investigate what mechanism and factors specific to Asia influence criminal and antisocial behaviors in order to develop criminology in Asia.

Yet, only pursuing such a singular-trait intensive strategy (Karstedt 2001) may not be enough to develop criminology in Asia. This is because our results also showed that those studies that incorporated singular cultural traits that are specific to the Asian context found no effect of these singular cultural traits. Given the limited number of such studies we have identified, it may just mean that singular cultural traits that are specific to the Asian context have yet to be sufficiently considered: for example, the effects of some potential singular cultural traits, such as Hinduism, are not examined. Or other contexts or conditions within Asia may yield different results. However, no effect of singular cultural trait in the Asian context may also mean that we should also employ the dimensional-extensive strategy (Karstedt 2001) in order to develop criminology in Asia. This is somewhat in line with the argument that modifications of existing criminological theories are needed to fit into the Asian context (Agnew 2015; Messner 2014, 2015; Miyazawa 1997) due to multi-dimensional cultural differences, such as collectivism (Liang and Lu 2006). 
To offer a complete picture of a future direction for the dimensional-extensive strategy for the Asian context is beyond the scope of this paper. In this regard, however, Liu (2016, 2017b) has recently proposed a potential approach: Asian Paradigm. According to it, Asia could differ from the "West" in three cultural values - (1) attachment, (2) honor, and (3) harmony ${ }^{7}$ - and each of these values might affect the (criminal) behaviors in Asian societies. At this point, it is not much clear how these cultural values can fit into the research context, but at least they can be a good starting point to advance the dimensional-extensive strategy for criminology in Asia. Without moving forward somehow, in relation to the three stages of the development of criminological theories in Asia - (1) transportation (i.e., testing existing theories), (2) transformation (i.e., modifying existing theories so as to fit to Asian contexts), and (3) establishment of "new" theories (Liu 2017a) - we continue to remain between the first and second stage, and will not be able to further develop criminology for Asia.

\section{Conclusion}

Although some studies, such as Hebenton and Jou (2013), have conducted a similar study, their analyses are limited to a specific Asian region, such as East Asia. Our paper is the first to show the overall trend of published English-written peer-reviewed journal articles across the entire Asian region. This is the central contribution of our paper for the sake of the development of criminology in Asia. Our results showed geographical, methodological, theoretical and conceptual gaps in the knowledge in the current empirical studies on criminological theories in Asia. Our findings encourage criminologists in Asia whose regions are underrepresented in the extant (English-written) literature, as well as give insights to those who are planning to conduct empirical studies in Asian regions.

\footnotetext{
${ }^{7}$ Although the definition of harmony is not clear, Liu (2016, p. 215) considers it important in the Asian context where a high value is placed upon "group/relationship harmony, conflict avoidance, self-sacrifice, and compromise when personal interests are harmed or personal conflict arises.”
} 
Criminology as a discipline in Asia has just started to develop. For instance, it is relatively recent that criminology as a major or criminology departments at the university level have become established in Asian countries (Hossain and Shahidullah 2008; Lee and Laidler 2013). While our results partly demonstrate the development of criminology in Asia, they also highlight a number of challenges. Without addressing these discrepancies in the extant literature, criminology in Asia remains at the nascent stage (Liu 2009; Liu et al. 2013). Particularly, criminologists in Asia should try to ask this question: With significant differences in cultures, regions, politics and economy within Asia, how do we construct/develop criminology in our own region? 


\section{Compliance with Ethical Standards}

\section{Funding}

No funding was received to complete this manuscript.

\section{Ethics Approval}

This article does not contain any studies with human participants or animals performed by any of the authors.

\section{Informed Consent}

Not applicable.

\section{Conflict of Interest}

The authors declare that they have no competing interests. 


\section{References}

Agnew, R. (2015). Using general strain theory to explain crime in Asian societies. Asian Journal of Criminology, 10(2), 131-147, doi:10.1007/s11417-014-9198-2.

Antonaccio, O., \& Botchkovar, E. V. (2016). What international research has told us about criminological theory. In A. R. Piquero (Ed.), The handbook of criminological theory (pp. 475-496). Surrey, UK: Wiley-Blackwell.

Baumer, E. P., \& Arnio, A. N. (2016). Macro-level theory: A critical component of criminological exploration. In A. R. Piquero (Ed.), The handbook of criminological theory (pp. 445-474). Surrey, UK: Wiley-Blackwell.

Belknap, J. (2016). Asian criminology's expansion and advancement of research and crime control practices. Asian Journal of Criminology, 11(4), 249-264, doi:10.1007/s11417016-9240-7.

Braithwaite, J. (2014). Crime in Asia: Toward a better future. Asian Journal of Criminology, 9(1), 65-75, doi:10.1007/s11417-013-9176-0.

Broadhurst, R., \& Liu, J. (2004). Introduction: Crime, law and criminology in China. Australian and New Zealand Journal of Criminology, 37(4), 1-12, doi:10.1375/000486504323020256.

Bryman, A. (2016). Social research methods (5ed.). Oxford, UK: Oxford University Press. Carrington, K. (2017). Asian criminology and southern epistemologies. In J. Liu, M. Travers, \& L. Y. C. Chang (Eds.), Comparative criminology in Asia (pp. 61-69): Springer.

Creswell, J. W. (2014). Research design: Qualitative, quantitative, and mixed methods approaches (4ed.). Thousand Oaks, CA: SAGE Publications.

Cullen, F. T., \& Wilcox, P. (Eds.). (2013). The Oxford handbook of criminological theory. Oxford, UK: Oxford University Press. 
Dien, D. S.-f. (1983). Big me and little me: A chinese perspective on self. Psychiatry, 46(3), 281-286.

Graham, H., \& McNeill, F. (2017). Desistance: Envisioning futures. In P. Carlen, \& L. A. França (Eds.), Alternative criminologies (pp. 433-451). London, UK: Routledge.

Hebenton, B., \& Jou, S. (2005). In search of criminological tradition: The development of criminology in Taiwan. Crime, Law and Social Change, 44(3), 215-250, doi:10.1007/s10611-005-9002-4.

Hebenton, B., \& Jou, S. (2013). Taiwan's criminological "footprint" - a review and analysis of english-language publication trends for Taiwan and selected Asian comparators (2000-2010). International Journal of Comparative and Applied Criminal Justice, $37(2), 159-173$.

Hossain, M., \& Shahidullah, S. M. (2008). Global-local nexus and the emerging field of criminology and criminal justice in South Asia: Bangladesh case. Bangladesh ejournal of sociology, 5(2), 51-60.

Jiang, S., \& Lambert, E. G. (2012). Introduction: Social control in asian countries. Asian Journal of Criminology, 7(2), 101-105, doi:10.1007/s11417-012-9125-3.

Jiang, S., Land, K. C., \& Wang, J. (2013). Social ties, collective efficacy and perceived neighborhood property crime in Guangzhou, China. Asian Journal of Criminology, 8(3), 207-223, doi:10.1007/s11417-013-9167-1.

Joo, H. J. (2015). Crime and criminal justice in South Korea: Editor's introduction. Asian Journal of Criminology, 10(1), 1-6, doi:10.1007/s11417-015-9209-y.

Karstedt, S. (2001). Comparing cultures, comparing crime: Challenges, prospects and problems for a global criminology. Crime, Law and Social Change, 36(3), 285-308, doi:10.1023/A:1012223323445. 
Karstedt, S. (2012). Comparing justice and crime across cultures. In D. Gadd, S. Karstedt, \& S. F. Messner (Eds.), The sage handbook of criminological research methods (pp. 373-389). Los Angeles, CA: SAGE.

Konishi, T. (2013). Diversity witin an Asian country: Japanese criminal justice and criminology. In J. Liu, B. Hebenton, \& S. Jou (Eds.), Handbook of Asian criminology (pp. 213-222). New York, NY: Springer.

Lee, M., \& Laidler, K. J. (2013). Doing criminology from the periphery: Crime and punishment in Asia. Theoretical Criminology, 17(2), 141-157, doi:10.1177/1362480613476790.

Liang, B., \& Lu, H. (2006). Conducting fieldwork in China: Observations on collecting primary data regarding crime, law, and the criminal justice system. Journal of Contemporary Criminal Justice, 22(2), 157-172, doi:10.1177/1043986206286918.

Liu, J. (2007). Developing comparative criminology and the case of China: An introduction. International Journal of Offender Therapy and Comparative Criminology, 51(1), 3-8, doi:10.1177/0306624X06295774.

Liu, J. (2009). Asian criminology - challenges, opportunities, and directions. Asian Journal of Criminology, 4(1), 1-9, doi:10.1007/s11417-009-9066-7.

Liu, J. (2016). Asian paradigm theory and access to justice. Journal of Contemporary Criminal Justice, 32(3), 205-224, doi:10.1177/1043986216656681.

Liu, J. (2017a). The asian criminological paradigm and how it links global north and south: Cobining an extended conceptual toolbox from the north with innovative Asian contexts. International Journal for Crime, Justice and Social Democracy, 6(1), 73-87.

Liu, J. (2017b). The new Asian paradigm: A relational approach. In J. Liu, M. Travers, \& L. Y. C. Chang (Eds.), Comparative criminology in Asia (pp. 17-32): Springer. 
Liu, J., Hebenton, B., \& Jou, S. (2013). Progress of Asian criminology: Editors' introduction. In J. Liu, B. Hebenton, \& S. Jou (Eds.), Handbook of Asian criminology (pp. 1-9). New York, NY: Springer.

Liu, J., Travers, M., \& Chang, L. Y. C. (2017). Reflecting on comparison: A view from Asia. In J. Liu, M. Travers, \& L. Y. C. Chang (Eds.), Comparative criminology in Asia (pp. 185-201): Springer.

Marshall, I. H., \& Enzmann, D. (2012). The generalizability of self-control theory. In J. Junger-Tas, I. H. Marshall, D. Enzmann, M. Killias, M. Steketee, \& B. Gruszczynska (Eds.), The many faces of youth crime: Contrasting theoretical perspectives on juvenile delinquency across countries and cultures (pp. 285-325). New York, NY: Springer.

McLaughlin, E., \& Newburn, T. (Eds.). (2010). The sage handbook of criminological theory. London, UK: SAGE Publications.

Mei, J., \& Wang, M. (2007). Social change, crime, and criminology in China. Crime \& Justice International, 23(97), 14-21.

Messner, S. F. (2014). Social institutions, theory development, and the promise of comparative criminological research. Asian Journal of Criminology, 9(1), 49-63, doi:10.1007/s11417-013-9175-1.

Messner, S. F. (2015). When west meets east: Generalizing theory and expanding the conceptual toolkit of criminology. Asian Journal of Criminology, 10(2), 117-129, doi:10.1007/s11417-014-9197-3.

Miyazawa, S. (1997). The enigma of Japan as a testing ground for cross-cultural criminological studies. In D. Nelken (Ed.), Comparing legal cultures (pp. 195-214). Aldershot, UK: Dartmouth. 
Ornatowski, G. K. (1996). Confucian ethics and economic development: A study of the adaptation of confucian values to modern japanese economic ideology and institutions. Journal of Socio-Economics, 25(5), 571-590, doi:10.1016/S10535357(96)90018-9.

Pickering, C., \& Byrne, J. (2013). The benefits of publishing systematic quantitative literature reviews for phd candidates and other early-career researchers. Higher Education Research \& Development, 33(3), 534-548, doi:10.1080/07294360.2013.841651.

Pickering, C., Grignon, J., Steven, R., Guitart, D., \& Byrne, J. (2015). Publishing not perishing: How research students transition from novice to knowledgeable using systematic quantitative literature reviews. Studies in Higher Education, 40(10), 17561769, doi:10.1080/03075079.2014.914907.

Piquero, A. R. (Ed.). (2016). The handbook of criminological theory. Surrey, UK: WileyBlackwell.

Takagi, D., \& Kawachi, I. (2014). Neighborhood social heterogeneity and crime victimization in Japan: Moderating effects of social networks. Asian Journal of Criminology, 9(4), 271-284, doi:10.1007/s11417-014-9191-9.

Tittle, C. R. (2016). Introduction: Theory and contemporary criminology. In A. R. Piquero (Ed.), The handbook of criminological theory (pp. 1-17). Surrey, UK: WileyBlackwell.

Travers, M. (2017). Asian values, crime and social change. In J. Liu, M. Travers, \& L. Y. C. Chang (Eds.), Comparative criminology in Asia (pp. 33-44): Springer.

United Nations Staistics Division (2016). Composition of macro geographical (continental) regions, geographical sub-regions, and selected economic and other groupings. Accessed April 232016 http://unstats.un.org/unsd/methods/m49/m49regin.htm\#asia. 
Wilson, D. B. (2009). Missing a critical piece of the pie: Simple document search strategies inadequate for systematic reviews. Journal of Experimental Criminology, 5(4), 1-12, doi:10.1007/s11292-009-9085-5.

Yokoyama, M. (2013). Development of criminology in Japan from a sociological perspective. In J. Liu, B. Hebenton, \& S. Jou (Eds.), Handbook of Asian criminology (pp. 223-230). New York, NY: Springer.

Zhang, L. (2008). Juvenile delinquency and justice in contemporary China: A critical review of the literature over 15 years. Crime, Law and Social Change, 50(3), 149-160, doi:10.1007/s10611-008-9137-1.

Zhang, L., Messner, S. F., \& Liu, J. (2008). A critical review of recent literature on crime and criminal justice in China: Research findings, challenges, and prospects (introduction). Crime, Law and Social Change, 50(3), 125-130, doi:10.1007/s10611-008-9134-4.

Zhang, L., Messner, S. F., \& Lu, J. (2007). Criminological research in contemporary china: Challenges and lessons learned from a large-scale criminal victimization survey. International Journal of Offender Therapy and Comparative Criminology, 51(1), 110121, doi:10.1177/0306624X06294430. 


\section{Appendix: Journal articles included for the analysis}

Aleassa, H., Pearson, J. M., \& McClurg, S. (2011). Investigating software piracy in Jordan: An extension of the theory of reasoned action. Journal of Business Ethics, 98(4), 663676, doi:10.1007/s10551-010-0645-4.

Aliverdinia, A., \& Pridemore, W. A. (2007). A first glimpse at narcotics offenders in an Islamic Republic: A test of an integrated model of drug involvement among a sample of men incarcerated for drug offenses in Iran. International Criminal Justice Review, 17(1), 27-44, doi:10.1177/1057567706298913.

Bao, W.-N., Haas, A., Chen, X., \& Pi, Y. (2014). Repeated strains, social control, social learning, and delinquency: Testing an integrated model of general strain theory in China. Youth \& Society, 46(3), 402-424, doi:10.1177/0044118X11436189.

Bao, W.-N., Haas, A., \& Pi, Y. (2004). Life strain, negative emotions, and delinquency: An empirical test of general strain theory in the People's Republic of China. International Journal of Offender Therapy and Comparative Criminology, 48(3), 281-297, doi:10.1177/0306624X03258686.

Bao, W.-N., Haas, A., \& Pi, Y. (2007). Life strain, coping, and delinquency in the People's Republic of China: An empirical test of general strain theory from a matching perspective in social support. International Journal of Offender Therapy and Comparative Criminology, 51(1), 9-24, doi:10.1177/0306624X06294428.

Chan, G. H.-Y. (2015). The effect of life-course transitions on delinquent behavior among youth in social withdrawal situation. Deviant Behavior, 36(12), 935-955, doi:10.1080/01639625.2014.977181.

Chan, H. C. O., \& Chui, W. H. (2013). Social bonds and school bullying: A study of Macanese male adolescents on bullying perpetration and peer victimization. Child \& Youth Care Forum, 42(6), 599-616, doi:10.1007/s10566-013-9221-2. 
Chan, H. C. O., \& Chui, W. H. (2015). Social bond and self-reported nonviolent and violent delinquency: A study of traditional low risk, at-risk, and adjudicated male Chinese adolescents. Child \& Youth Care Forum, 44(5), 711-730, doi:10.1007/s10566-0159303-4.

Chan, H. C. O., \& Wong, D. S. W. (2015). The overlap between school bullying perpetration and victimization: Assessing the psychological, familial, and school factors of chinese adolescents in Hong Kong. Journal of Child and Family Studies, 24(11), 3224-3234, doi:10.1007/s10826-015-0125-7.

Cheung, C.-K. (2014). Delinquent risks of parental abuse at the age of 11 years among at-risk youth. Early Child Development and Care, 184(9-10), 1458-1471, doi:10.1080/03004430.2014.901014.

Cheung, C.-K., Ngai, N.-P., \& Ngai, S. S.-Y. (2007). Family strain and adolescent delinquency in two Chinese cities, Guangzhou and Hong Kong. Journal of Child and Family Studies, 16(5), 626-641, doi:10.1007/s10826-006-9112-3.

Cheung, C. K. (2013). Understanding factors associated with online piracy behaviour of adolescents. International Journal of Adolescence and Youth, 18(2), 122-132, doi:10.1080/02673843.2012.669837.

Cheung, N. W. T. (2014). Low self-control and co-occurrence of gambling with substance use and delinquency among Chinese adolescents. Journal of Gambling Studies, 30(1), 105-124, doi:10.1007/s10899-012-9351-8.

Cheung, N. W. T., \& Cheung, Y. W. (2008). Self-control, social factors, and delinquency: A test of the general theory of crime among adolescents in Hong Kong. Journal of Youth and Adolescence, 37(4), 412-430, doi:10.1007/s10964-007-9218-y. 
Cheung, N. W. T., \& Cheung, Y. W. (2010). Strain, self-control, and gender differences in delinquency among Chinese adolescents: Extending general strain theory. Sociological Perspectives, 53(3), 321-345.

Chu, M. M. (2002). Incarcerated Chinese men: Their life experiences and criminal onset. British Journal of Criminology, 42(2), 250-266, doi:10.1093/bjc/42.2.250.

Chui, W. H., \& Chan, H. C. (2011). Social bonds and male juvenile delinquency while on probation: An exploratory test in Hong Kong. Children and Youth Services Review, 33(11), 2329-2334, doi:10.1016/j.childyouth.2011.08.003.

Chui, W. H., \& Chan, H. C. (2013a). Association between self-control and school bullying behaviors among Macanese adolescents. Child Abuse and Neglect, 37(4), 237-242, doi:10.1016/j.chiabu.2012.12.003.

Chui, W. H., \& Chan, H. C. (2013b). Psychological characteristics of male 14- to 20-yearolds on probation and in a residential home in Hong Kong. Criminal Behaviour and Mental Health, 23(1), 41-55, doi:10.1002/cbm.1851.

Chui, W. H., \& Chan, H. C. O. (2012a). Criminal recidivism among Hong Kong male juvenile probationers. Journal of Child and Family Studies, 21(5), 857-868, doi:10.1007/s10826-011-9546-0.

Chui, W. H., \& Chan, H. C. O. (2012b). An empirical investigation of social bonds and juvenile delinquency in Hong Kong. Child \& Youth Care Forum, 41(4), 371-386, doi:10.1007/s10566-012-9172-z.

Chui, W. H., \& Chan, H. C. O. (2015). Self-control, school bullying perpetration, and victimization among Macanese adolescents. Journal of Child and Family Studies, 24(6), 1751-1761, doi:10.1007/s10826-014-9979-3. 
Cohen, B.-Z., \& Zeira, R. (1999). Social control, delinquency, and victimization among Kibbutz adolescents. International Journal of Offender Therapy and Comparative Criminology, 43(4), 503-513, doi:10.1177/0306624X99434008.

Cretacci, M. A., Fei, M. L. D., \& Rivera, C. J. (2010). Traditional and bond measures of selfcontrol and their impact on deviance among Chinese university students. International Journal of Criminal Justice Sciences, 5(1), 220.

Cretacci, M. A., Rivera, C. J., \& Ding, F. (2009). Self-control and Chinese deviance: A look behind the bamboo curtain. International Journal of Criminal Justice Sciences, 4(2), 131.

Denq, F., Vaughn, M. S., \& Huang, F. F. Y. (1994). Correlates of crime in Taiwan: S timeseries analysis from 1964 to 1990. Crime, Law and Social Change, 21(3), 267-285, doi:10.1007/BF01307967.

Eisikovits, Z., Winstok, Z., \& Fishman, G. (2004). The first Israeli national survey on domestic violence. Violence Against Women, 10(7), 729-748, doi:10.1177/107780120465549.

Emery, C. R., Nguyen, H. T., \& Kim, J. (2014). Understanding child maltreatment in Hanoi: Intimate partner violence, low self-control, and social and child care support. Journal of Interpersonal Violence, 29(7), 1228-1257, doi:10.1177/0886260513506276.

Farrington, D. P., Harada, Y., Shinkai, H., \& Moriya, T. (2015). Longitudinal and criminal career research in Japan. Asian Journal of Criminology, 10(4), 255-276, doi:10.1007/s11417-015-9222-1.

Gao, Y., Dennis, S. W. W., \& Yu, Y. (2016). Maltreatment and delinquency in China: Examining and extending the intervening process of general strain theory. International Journal of Offender Therapy and Comparative Criminology, 60(1), 3861, doi:10.1177/0306624X14547495. 
Haj-yahia, M. M. (1998). Perceptions of abusive and violent husbands by engaged Arab men in Israel. The Journal of Social Psychology, 138(6), 772-786, doi:10.1080/00224549809603263.

Han, C.-R., Nelen, H., \& Joo, M. Y. (2015). Documentary credit fraud against banks: Analysis of Korean cases. Journal of Money Laundering Control, 18(4), 457-474, doi:10.1108/JMLC-12-2014-0048.

Hershkowitz, I. (2011). The effects of abuse history on sexually intrusive behavior by children: An analysis of child justice records. Child Abuse \& Neglect, 35(1), 40-49, doi:10.1016/j.chiabu.2010.09.002.

Hershkowitz, I. (2014). Sexually intrusive behavior among alleged CSA male victims: A prospective study. Sexual Abuse, 26(3), 291-305, doi:10.1177/1079063213486937.

Hilal, S. M., Densley, J. A., Li, S. D., \& Ma, Y. (2014). The routine of mass murder in China. Homicide Studies, 18(1), 83-104, doi:10.1177/1088767913505092.

Hindin, M. J., \& Adair, L. S. (2002). Who's at risk? Factors associated with intimate partner violence in the Philippines. Social Science \& Medicine, 55(8), 1385-1399, doi:10.1016/S0277-9536(01)00273-8.

Jang, S. J., \& Song, J. (2015). A "rough test" of a delinquent coping process model of general strain theory. Journal of Criminal Justice, 43(6), 419-430, doi:10.1016/j.jcrimjus.2015.08.003.

Jennings, W. G., Park, M., Richards, T. N., Tomsich, E., Gover, A., \& Powers, R. A. (2014). Exploring the relationship between child physical abuse and adult dating violence using a causal inference approach in an emerging adult population in South Korea. Child Abuse \& Neglect, 38(12), 1902-1913, doi:10.1016/j.chiabu.2014.08.014.

Jennings, W. G., Park, M., Tomsich, E. A., Gover, A. R., \& Akers, R. L. (2011). Assessing the overlap in dating violence perpetration and victimization among South Korean 
college students: The influence of social learning and self-control. American Journal of Criminal Justice, 36(2), 188-206, doi:10.1007/s12103-011-9110-х.

Jo, Y. (2015). Stability of self-control: Hirschi’s redefined self-control. International Journal of Offender Therapy and Comparative Criminology, 59(1), 51-67, doi:10.1177/0306624X13501839.

Jo, Y., \& Bouffard, L. (2014). Stability of self-control and gender. Journal of Criminal Justice, 42(4), 356-365, doi:10.1016/j.jcrimjus.2014.05.001.

Jo, Y., \& Zhang, Y. (2014). Parenting, self-control, and delinquency: Examining the applicability of Gottfredson and Hirschi's general theory of crime to South Korean youth. International Journal of Offender Therapy and Comparative Criminology, 58(11), 1340-1363, doi:10.1177/0306624X13494670.

Karaman, N. G. (2013). Predicting the problem behavior in adolescents. Eurasian Journal of Educational Research, 52, 137-154.

Kasim, M. S., Mohd. Shafie, H., \& Cheah, I. (1994). Social factors in relation to physical abuse in Kuala Lumpur, Malaysia. Child Abuse \& Neglect, 18(5), 401-407, doi:10.1016/0145-2134(94)90025-6.

Kerley, K. R., Xu, X., \& Sirisunyaluck, B. (2008). Self-control, intimate partner abuse, and intimate partner victimization: Testing the general theory of crime in Thailand. Deviant Behavior, 29(6), 503-532, doi:10.1080/01639620701673156.

Kerley, K. R., Xu, X., Sirisunyaluck, B., \& Alley, J. M. (2010). Exposure to family violence in childhood and intimate partner perpetration or victimization in adulthood: Exploring intergenerational transmission in urban Thailand. Journal of Family Violence, 25(3), 337-347, doi:10.1007/s10896-009-9295-7. 
Kim, B., Geber, J., \& Kim, Y. (2007). Characteristics of incarcerated women in South Korea who killed their spouses: A feminist and age-graded theory of informal social control analysis. The Southwest Journl of Criminal Justice, 4(1), 39-57.

Kim, B., Gerber, J., Henderson, C., \& Kim, Y. (2012). Applicability of general power-control theory to prosocial and antisocial risk-taking behaviors among women in South Korea. The Prison Journal, 92(1), 125-150, doi:10.1177/0032885511429275.

Kim, E., Akers, R. L., \& Yun, M. (2013). A cross-cultural test of social structure and social learning: Alcohol use among South Korean adolescents. Deviant Behavior, 34(11), 895-915, doi:10.1080/01639625.2013.782787.

Kim, E., Kwak, D.-H., \& Yun, M. (2010). Investigating the effects of peer association and parental influence on adolescent substance use: A study of adolescents in South Korea. Journal of Criminal Justice, 38(1), 17-24, doi:10.1016/j.jcrimjus.2009.11.003.

Kim, J. E., \& Kim, J. (2015). International note: Teen users' problematic online behavior: Using panel data from South Korea. Journal of Adolescence, 40, 48-53, doi:10.1016/j.adolescence.2015.01.001.

Kobayashi, E., \& Kerbo, H. R. (2016). The deterrent effects of punishments for noncompliance and rewards for compliance: A comparison of hospital employees in Japan and the United States. Deviant Behavior, 37(9), 1077-1094, doi:10.1080/01639625.2016.1169742.

Kobayashi, E., Sharp, S. F., \& Grasmick, H. G. (2008). Gender and deviance: A comparison of college students in Japan and the United States. Deviant Behavior, 29(5), 413-439, doi:10.1080/01900690701598010.

Landau, S. F., \& Fridman, D. (1993). The seasonality of violent crime: The case of robbery and homicide in Israel. Journal of Research in Crime and Delinquency, 30(2), 163191, doi:10.1177/0022427893030002003. 
Law, F. M., \& Guo, G. J. (2014). Who is in charge of your recovery? The effectiveness of reality therapy for female drug offenders in Taiwan. International Journal of Offender Therapy and Comparative Criminology, 58(6), 672-696, doi:10.1177/0306624X12474976.

Lee, C. H., Moak, S., \& Walker, J. T. (2016). Effects of self-control, social control, and social learning on sexting behavior among South Korean youths. Youth \& Society, 48(2), 242-264, doi:10.1177/0044118X13490762.

Lee, E. J., \& Bukowski, W. M. (2012). Co-development of internalizing and externalizing problem behaviors: Causal direction and common vulnerability. Journal of adolescence, 35(3), 713-729, doi:10.1016/j.adolescence.2011.10.008.

Lee, J., Onifade, E., Teasley, M., \& Noel, L. (2012). The effects of risk and protective factors on juvenile delinquency in South Korea. Journal of Ethnicity in Criminal Justice, 10(4), 316-329, doi:10.1080/15377938.2012.732880.

Lim, S. S., Basnyat, I., Vadrevu, S., \& Chan, Y. H. (2013). Critical literacy, self-protection and delinquency: The challenges of participatory media for youths at-risk. Learning, Media and Technology, 38(2), 145-160.

Lin, W.-H. (2012). General strain theory in Taiwan: A latent growth curve modeling approach. Asian Journal of Criminology, 7(1), 37-54, doi:10.1007/s11417-010-91018.

Lin, W.-H., Dembo, R., Sellers, C. S., Cochran, J., \& Mieczkowski, T. (2014). Strain, negative emotions, and juvenile delinquency: The United States versus Taiwan. International Journal of Offender Therapy and Comparative Criminology, 58(4), 412434, doi:10.1177/0306624X13492656. 
Lin, W.-H., \& Mieczkowski, T. (2011). Subjective strains, conditioning factors, and juvenile delinquency: General strain theory in Taiwan. Asian Journal of Criminology, 6(1), 6987, doi:10.1007/s11417-009-9082-7.

Lin, W. H., \& Yi, C. C. (2016). Family and school strains and their effects on adolescent deviance in Taiwan: A mediating study. Youth \& Society, 48(4), 496-520, doi:10.1177/0044118X13499595.

Liu, R. X. (2011). Strain as a moderator of the relationship between parental attachment and delinquent participation: A China study. International Criminal Justice Review, 21(4), 427-442, doi:10.1177/1057567711431127.

Liu, R. X. (2012). The effects of strain and centrality of strain on delinquency among Chinese adolescents: The effects of strain and centrality of strain. Sociological Inquiry, 82(4), 578-600, doi:10.1111/j.1475-682X.2012.00427.x.

Liu, R. X., \& Lin, W. (2007). Delinquency among Chinese adolescents: Modeling sources of frustration and gender differences. Deviant Behavior, 28(5), 409-432, doi:10.1080/01639620701233316.

Lu, Y.-F., Yu, Y.-C., Ren, L., \& Marshall, I. H. (2013). Exploring the utility of self-control theory for risky behavior and minor delinquency among Chinese adolescents. Journal of Contemporary Criminal Justice, 29(1), 32-52, doi:10.1177/1043986212471240.

Maimon, D., Wilson, T., Ren, W. L., \& Berenblum, T. (2015). On the relevance of spatial and temporal dimensions in assessing computer susceptibility to system trespassing incidents. British Journal of Criminology, 55(3), 615-634, doi:10.1093/bjc/azu104.

Maxwell, S. R. (2001). A focus on familial strain: Antisocial behavior and delinquency in Filipino society. Sociological Inquiry, 71(3), 265-292, doi:10.1111/j.1475682X.2001.tb01113.x. 
Mesch, G. S., Fishman, G., \& Eisikovits, Z. (2003). Attitudes supporting violence and aggressive behavior among adolescents in Israel: The role of family and peers. Journal of Interpersonal Violence, 18(10), 1132-1148, doi:10.1177/0886260503255552.

Mon, W.-T. (2002). Causal factors of corporate crime in Taiwan: Qualitative and quantitative findings. International Journal of Offender Therapy and Comparative Criminology, 46(2), 183-205, doi:10.1177/0306624X02046002005.

Moon, B., Blurton, D., \& McCluskey, J. D. (2008). General strain theory and delinquency: Focusing on the influences of key strain characteristics on delinquency. Crime \& Delinquency, 54(4), 582-613, doi:10.1177/0011128707301627.

Moon, B., Hwang, H.-W., \& McCluskey, J. D. (2011). Causes of school bullying: Empirical test of a general theory of crime, differential association theory, and general strain theory. Crime \& Delinquency, 57(6), 849-877, doi:10.1177/0011128708315740.

Moon, B., McCluskey, C. P., \& McCluskey, J. D. (2010). A general theory of crime and computer crime: An empirical test. Journal of Criminal Justice, 38(4), 767-772, doi:10.1016/j.jcrimjus.2010.05.003.

Moon, B., McCluskey, J. D., Blurton, D., \& Hwang, H.-W. (2014). Parent and teacher practices as sources of low self-control: Evidence from Korea. Youth Violence and Juvenile Justice, 12(2), 167-187, doi:10.1177/1541204013481982.

Moon, B., McCluskey, J. D., McCluskey, C. P., \& Lee, S. (2013). Gender, general theory of crime and computer crime: An empirical test. International Journal of Offender Therapy and Comparative Criminology, 57(4), 460-478, doi:10.1177/0306624X11433784.

Moon, B., Morash, M., McCluskey, C. P., \& Hwang, H.-W. (2009). A comprehensive test of general strain theory: Key strains, situational- and trait-based negative emotions, 
conditioning factors, and delinquency. Journal of Research in Crime and Delinquency, 46(2), 182-212, doi:10.1177/0022427808330873.

Moon, B., Morash, M., \& McCluskey, J. D. (2012). General strain theory and school bullying: An empirical test in South Korea. Crime\& Delinquency, 58(6), 827-855, doi:10.1177/0011128710364809.

Morash, M., \& Moon, B. (2007). Gender differences in the effects of strain on the delinquency of South Korean youth. Youth \& Society, 38(3), 300-321, doi:10.1177/0044118X06287861.

Motoaki, H., Souma, I., Kimura, H., \& Shigehisa, T. (1990). Behavioral characteristics of juvenile deviators in Japan: A study of the current status of deviant behavior among japanese high school boys and girls. Japanese Psychological Research, 32(4), 181191.

Ngai, N.-P., \& Cheung, C.-K. (2005). Predictors of the likelihood of delinquency: A study of marginal youth in Hong Kong, China. Youth \& Society, 36(4), 445-470, doi:10.1177/0044118X04265090.

Ngai, N. P., Cheung, C. K., \& Ngai, S. S. Y. (2007). Cognitive and social influences on gang involvement among delinquents in three Chinese cities. Adolescence, 42(166), 381403.

Ngai, S. S.-y., \& Cheung, C.-Y. (2005). When does career strain reduce delinquency? Friendship concern in Hong Kong. International Journal of Adolescence and Youth, 12(1-2), 131-147, doi:10.1080/02673843.2005.9747947.

Özbay, Ö. (2008). Self-control, gender, and deviance among Turkish university students. Journal of Criminal Justice, 36(1), 72-80, doi:10.1016/j.jcrimjus.2007.12.009. 
Özbay, Ö., \& Köksoy, O. (2009). Is low self-control associated with violence among youths in Turkey? International Journal of Offender Therapy and Comparative Criminology, 53(2), 145-167, doi:10.1177/0306624X08314577.

Özbay, Ö., \& Özcan, Y. Z. (2006). Classic strain theory and gender: The case of Turkey. International Journal of Offender Therapy and Comparative Criminology, 50(1), 2138, doi:10.1177/0306624X05277665.

Ozen, S., Ece, A., Oto, R., Tirasci, Y., \& Goren, S. (2005). Juvenile delinquency in a developing country: A province example in Turkey. International Journal of Law and Psychiatry, 28(4), 430-441, doi:10.1016/j.ijlp.2005.05.001.

Pyrooz, D. C., \& Decker, S. H. (2013). Delinquent behavior, violence, and gang involvement in China. Journal of Quantitative Criminology, 29(2), 251-272, doi:10.1007/s10940012-9178-6.

Roberts, A., \& LaFree, G. (2004). Explaining Japan's postwar violent crime trends. Criminology, 42(1), 179-209, doi:10.1111/j.1745-9125.2004.tb00517.x.

Sacarellos, C. D., Wright, J. P., Almosaed, N. F., Moghrabi, S. S., Bashatah, F. S., \& Morgan, M. A. (2016). Crime in the kingdom: The effects of low self-control in a Saudi Arabian sample of youth. Youth Violence and Juvenile Justice, 14(3), 291-312, doi:10.1177/1541204015616663.

Shechory-Bitton, M., \& Kamel, D. (2014). Pathways to crime and risk factors among Arab female adolescents in Israel. Children and Youth Services Review, 44, 363-369, doi:10.1016/j.childyouth.2014.04.004.

Shechory, M., \& Laufer, A. (2008). Social control theory and the connection with ideological offenders among Israeli youth during the Gaza disengagement period. International Journal of Offender Therapy and Comparative Criminology, 52(4), 454-473, doi:10.1177/0306624X07307353. 
Shechory, M., \& Laufer, A. (2011). Ideological delinquency: Gender differences among Israeli youth during the withdrawal from the Gaza strip. International Journal of Offender Therapy and Comparative Criminology, 55(2), 326-343, doi:10.1177/0306624X09352618.

Shechory, M., Perry, G., \& Addad, M. (2011). Pathways to women's crime: Differences among women convicted of drug, violence and fraud offenses. The Journal of Social Psychology, 151(4), 399-416, doi:10.1080/00224545.2010.503721.

Shoemaker, D. J. (1994). Male-female delinquency in the Philippines: A comparative analysis. Youth \& Society, 25(3), 299-329, doi:10.1177/0044118X94025003001.

Shoham, S., \& Hovav, M. (1966). Social factors, aspects of treatment, and patterns of criminal career among the B'nei-Tovim: A study of upper-and middle-class juvenile delinquency in Israel. Human Relations, 19(1), 47-56, doi:10.1177/001872676601900104.

Simhadri, Y. C. (1978). Differential association and denotified tribes. Indian Journal of Social Work, 39(2), 161-174.

Statland-Vaintraub, O., Khoury-Kassabri, M., Ajzenstadt, M., \& Amedi, S. (2012). Risk factors for involvement in delinquency among immigrants and native-born Israeli girls. Children and Youth Services Review, 34(10), 2052-2060, doi:10.1016/j.childyouth.2012.06.013.

Sun, I. Y., Luo, H. S., Wu, Y. N., \& Lin, W. H. (2016). Strain, negative emotions, and level of criminality among Chinese incarcerated women. International Journal of Offender Therapy and Comparative Criminology, 60(7), 828-846, doi:10.1177/0306624X15595412. 
Tanioka, I., \& Glaser, D. (1991). School uniforms, routine activities, and the social control of delinquency in Japan. Youth \& Society, 23(1), 50-75, doi:10.1177/0044118X91023001003.

Taylor, T. J., Friday, P. C., Ren, X., Weitekamp, E. G. M., \& Kerner, H.-J. (2004). Risk and protective factors related to offending: Results from a Chinese cohort study. Australian and New Zealand Journal of Criminology, 37(4), 13-31.

Timor, U. (2001). Balagan: Delinquency as a result of the lack of a center of norms and consciousness. International Journal of Offender Therapy and Comparative Criminology, 45(6), 730-748, doi:10.1177/0306624X01456007.

Ulusoy, M. D. (2008). Adolescent delinquency: A study from in Ankara, Turkey. International Journal of Child and Adolescent Health, 1(3), 207-218.

Ünal, H., \& Çukur, C. Ş. (2011). The effects of school bonds, discipline techniques in school and victimization on delinquency of high school students. Kuram ve Uygulamada Egitim Bilimleri, 11(2), 560-570.

Vazsonyi, A. T., Wittekind, J. E. C., Belliston, L. M., \& Van Loh, T. D. (2004). Extending the general theory of crime to "the East": Low self-control in Japanese late adolescents. Journal of Quantitative Criminology, 20(3), 189-216, doi:10.1023/B:JOQC.0000037731.28786.e3.

Walsh, S. D., Fogel-Grinvald, H., \& Shneider, S. (2015). Discrimination and ethnic identity as predictors of substance use and delinquency among immigrant adolescents from the FSU and Ethiopia in Israel. Journal of Cross-Cultural Psychology, 46(7), 942963, doi:10.1177/0022022115588951

Wickersham, J. A., Loeliger, K. B., Marcus, R., Pillai, V., Kamarulzaman, A., \& Altice, F. L. (2016). Patterns of substance use and correlates of lifetime and active injection drug 
use among women in Malaysia. The American Journal of Drug and Alcohol Abuse, 42(1), 98-110, doi:10.3109/00952990.2015.1101467.

Wong, D. S. W. (2001). Pathways to delinquency in Hong Kong and Guangzhou (South China). International Journal of Adolescence and Youth, 10(1-2), 91-115, doi:10.1080/02673843.2001.9747893.

Yang, X., \& Xia, G. (2010). Causes and consequences of increasing club drug use in China: A descriptive assessment. Substance Use \& Misuse, 45(1-2), 224-239, doi:10.3109/10826080903039827.

Yi, S., Poudel, K. C., Yasuoka, J., Palmer, P. H., Yi, S., \& Jimba, M. (2011). Risk vs. Protective factors for substance use among adolescents in Cambodia. Journal of Substance Use, 16(1), 14-26, doi:10.3109/14659890903531261.

Yonai, S., Levine, S. Z., \& Glicksohn, J. (2013). A national population based examination of the association between age-versatility trajectories and recidivism rates. Journal of Criminal Justice, 41(6), 467-476, doi:10.1016/j.jcrimjus.2013.09.007.

Yun, I., \& Lee, C. H. (2015). Hazardous alcohol use among South Korean police officers: Examining predictions from general strain theory. International Journal of Law, Crime and Justice, 43(2), 194-213, doi:10.1016/j.ijlcj.2014.08.002.

Yun, I., \& Walsh, A. (2011). The stability of self-control among South Korean adolescents. International Journal of Offender Therapy and Comparative Criminology, 55(3), 445459, doi:10.1177/0306624X09358072.

Yun, M., \& Kim, E. (2015). Illicit drug use among South Korean offenders: Assessing the generality of social learning theory. International Journal of Offender Therapy and Comparative Criminology, 59(11), 1166-1187, doi:10.1177/0306624X14530671. 
Yun, M., Kim, E., \& Morris, R. (2014). Gendered pathways to delinquency: An examination of general strain theory among South Korean youth. Youth Violence and Juvenile Justice, 12(3), 268-292, doi:10.1177/1541204013497769.

Zemel, O., Ronel, N., \& Einat, T. (2016). The impact of introspection and resilience on abstention and desistance from delinquent behavior among adolescents at risk. European Journal of Criminology, 13(1), 111-111, doi:10.1177/1477370815587770.

Zeng, G., Chu, C. M., \& Lee, Y. (2015). Assessing protective factors of youth who sexually offended in Singapore: Preliminary evidence on the utility of the DASH-13 and the SAPROF. Sexual Abuse, 27(1), 91-108, doi:10.1177/1079063214561684.

Zhang, L., \& Messner, S. F. (1999). Bonds to the work unit and official offense status in urban China. International Journal of Offender Therapy and Comparative Criminology, 43(3), 375-390, doi:10.1177/0306624X99433009. 